\title{
"My" Hero or Epic Fail? Torchwood as Transnational Telefantasy
}

\section{Melissa Beattie ${ }^{1}$}

Recibido: 2016-09-19

Enviado a pares: 2016-09-19
Aprobado por pares: 2017-02-17

Aceptado: 2017-03-23

DOI: 10.5294/pacla.2017.20.3.7

Para citar este artículo / to reference this article / para citar este artigo

Beattie, M. (2017). "My" hero or epic fail? Torchwood as transnational telefantasy.

Palabra Clave, 20(3), 722-762. DOI: 10.5294/pacla.2017.20.3.7

\section{Abstract}

Telefantasy series Torchwood (2006-2011, multiple production partners) was industrially and paratextually positioned as being Welsh, despite its frequent status as an international co-production. When, for series 4 (subtitled Miracle Day, much as the miniseries produced as series 3 was subtitled Children of Earth), the production (and diegesis) moved primarily to the United States as a co-production between BBC Worldwide and American premium cable broadcaster Starz, fan response was negative from the announcement, with the series being termed Americanised in popular and academic discourse. This study, drawn from my doctoral research, which interrogates all of these assumptions via textual, industrial/contextual and audience analysis focusing upon ideological, aesthetic and interpretations of national identity representation, focuses upon the interactions between fan cultural capital and national cultural capital and how those interactions impact others of the myriad of reasons why the (re)glocalisation failed. It finds that, in part due to the competing public service and commercial ideologies of the BBC, Torchwood was a glocalised text from the beginning, despite its positioning as Welsh, which then became glocalised again in series 4. Audience response often expressed the contradictory historical and con-

1 Independent Scholar. United Kindom. tritogeneia@aol.com 
temporary discourses associated with British and American "quality TV." Therefore, this study qualitatively investigates the various readings produced by audience members in the US, UK and Canada, as well as transnational fans who are long-term residents of one of those nations with a focus upon the interactions between fan and national cultural capital. The study finds that the audience is pseudo-reflexive when it comes to interpretation; though all express an awareness and acceptance that national identity is constructed and fluid, they still express an underlying essentialism when discussing national identity in the context of the series.

\section{Keywords}

Glocalisation; transnational television; national identity; telefantasy; fan cultural capital; national cultural capital (Source: Unesco Thesaurus). 


\section{¿"Mi" héroe 0 un total fracaso? Torchwood como tele fantasía trasnacional}

\section{Resumen}

La serie tele fantástica Torchwood (2006-2011, de múltiples productoras) se posicionó industrial y paratextualmente como una serie galesa, a pesar de su frecuente condición de coproducción internacional. Cuando en la cuarta temporada (subtitulada Miracle Day, del mismo modo en que la tercera temporada se subtituló Children of Earth), la producción (y diégesis) se trasladó principalmente a Estados Unidos como una coproducción entre BBC Worldwide y el canal de televisión premium estadounidense Starz, los seguidores de la serie reaccionaron de forma negativa al anuncio y la calificaron como "americanizada" en el discurso popular y académico. Este estudio, elaborado a partir de mi investigación doctoral, examina todas estas suposiciones a través de un análisis textual, industrial/contextual y de audiencia que se enfoca en las interacciones entre el capital cultural de los aficionados y el capital cultural nacional, y en cómo dichas interacciones impactan a otras de las miles de razones del fracaso de la (re)glocalización. Los resultados muestran que, en parte por la competencia entre el servicio público y las ideologías comerciales de la BBC, Torchwood fue un texto glocalizado desde sus inicios, a pesar de posicionarse como una serie galesa, que posteriormente se glocalizó nuevamente en la cuarta temporada. La respuesta de la audiencia a menudo expresaba los contradictorios discursos históricos y contemporáneos asociados con la "televisión de calidad” británica y americana. Por consiguiente, este estudio realiza una investigación cualitativa de las diversas lecturas de los miembros de la audiencia en Estados Unidos, el Reino Unido y Canadá, así como de los aficionados transnacionales residentes de largo plazo de una de esas naciones, enfocándose en las interacciones entre el capital cultural nacional y el de los aficionados. El estudio encuentra que la audiencia es pseudo-reflexiva en cuanto a la interpretación; aunque todos expresan ser conscientes y aceptar que la identidad nacional es construi- 
da y fluida, aún expresan un esencialismo subyacente al discutir la identidad nacional en el contexto de la serie.

\section{Palabras clave}

Glocalización, televisión trasnacional, identidad nacional, tele fantasía, capital cultural de los fans, capital cultural nacional (Fuente: Tesauro de la Unesco). 


\section{"Meu" herói ou um fracasso total? Torchwood como tele fantasia transnacional}

\section{Resumo}

A série tele fantástica Torchwood (2006-2011, de múltiplos produtores) se posicionou industrial e paratextualmente como um seriado galês, apesar de sua frequente condição de coprodução internacional. Quando na quarta temporada (chamada de Miracle Day, do mesmo jeito que a terceira temporada foi chamada de Children of Earth), a produção (e diegese) se mudou principalmente aos Estados Unidos como uma coprodução entre BBC Worldwide e o canal de televisão premium estadunidense Starz, os seguidores da série reagiram de forma negativa ao anúncio e a chamaram de "americanizada" no discurso popular e acadêmico. Este estudo, elaborado a partir de minha pesquisa doutoral, examina todas estas suposições por meio de uma análise textual, industrial/contextual e de audiência que se concentra nas interações entre o capital cultural dos fãs e o capital cultural nacional, e na maneira em que estas interações impactam as outras das muitas razões do fracasso da (re)glocalização. Os resultados mostram que, em parte pela competência entre o serviço público e as ideologias comerciais da BBC, Torchwood foi um texto glocalizado desde um princípio, apesar de posicionar-se como uma série galesa, que posteriormente se glocalizou mais uma vez na quarta temporada. A resposta da audiência frequentemente expressava os contraditórios discursos históricos e contemporâneos associados com a "televisão de qualidade" britânica e americana. Por conseguinte, este estudo realiza uma pesquisa qualitativa das diversas leituras dos membros da audiência nos Estados Unidos, o Reino Unido e o Canadá, e também dos aficionados transnacionais residentes em uma de essas nações, com um foco nas interações entre o capital cultural nacional e o capital cultural dos fãs. $\mathrm{O}$ estudo revela que a audiência é pseudo-reflexiva em quanto à interpretação; mesmo que todos expressem ser conscientes e aceitar que a identidade nacional é construída e flu- 
ida, ainda expressam um essencialismo subjacente ao discutir a identidade nacional no contexto da série.

\section{Palavras-chave}

Glocalização; televisão transnacional; identidade nacional; tele fantasia; capital cultural dos fãs; capital cultural nacional (Fonte: Tesauro da Unesco). 


\section{Introduction}

Though there has been an increasing interest in the glocalisation of media, what tends to be focused upon in academic research are the successes. Therefore, in this paper, I shall be examining one of the more notable failures: that of the telefantasy series Torchwood (2006). Using data drawn from my doctoral research, including quotations from my interview respondents and focus groups, I have determined that there were multiple, sometimes contradictory, reasons why the fourth series was a critical and popular failure. Though each facet would be a paper in itself, for this article I shall focus primarily upon the interaction of fan cultural capital and national cultural capital.

Before I begin my discussion of the various elements of theory involved in this study, I must first briefly explain the relevant aspects of the series. Torchwood was a spin-off of British telefantasy series par excellence, Doctor Who (Newman, Webber, \& Wilson, 1963). Designed to cater to an "adult" audience, rather than the family audience of the parent series, Torchwood initially focused upon the difficulties faced by a splinter team fighting (predominantly) aliens from a small base in Cardiff. Its first series was a co-production between the Canadian Broadcasting Corporation (CBC) and $\mathrm{BBC}$ Wales, with its second series being a production solely of $\mathrm{BBC}$ Wales. After two 13-episode series, the show's third series was a miniseries of five episodes shown on consecutive nights, again solely produced by BBC Wales. All of these were shot almost exclusively in South Wales (a few exteriors were in London in series three) and were set primarily in South Wales, with two scenes of uncertain location in series two and a large portion of series three taking place in London. The series was paratextually positioned as "Welsh sci-fi", with several interviews focusing upon the visual quality of Cardiff (Lacey, 2013) as well as connecting the series with BBC America's branding of "Cool, but Quality" and the "Cool Cymru" iteration of the "Cool Britannia" brand (James, 2013).

It is in series 4 that the major change with regard to glocalisation occurs. That series was comprised of a ten-episode serial that was co-produced by American premium cable broadcaster Starz and the BBC's commercial arm, 
BBC Worldwide; the New York Times referred to it as a BBC production for Starz, implying that the BBC were employed by (and therefore subordinate to) Starz. The series was primarily shot in the US (with three weeks of exterior shooting done in Wales) and primarily set outside Wales, mostly in the US, with brief segments set in China and Argentina. This also impacted the casting and the crew selection, as well as the broadcast schedule, with Americans seeing the episodes on a Sunday night and the British audience on the following Thursday. Despite these changes in production, the BBC still attempted to position the series as Welsh:

\begin{abstract}
Last week I stood on the steps of City Hall in Los Angeles watching an episode of Torchwood being shot. A large American crew, substantial American investment, a programme filmed on location in the United States and in Wales and seen by audiences around the world including licence payers in the UK-but a core creative team which is Welsh to its fingertips. (Thompson, 2011)
\end{abstract}

This statement by the then-Director General of the BBC, though problematic on many levels (e.g., the primordialist assumptions inherent in "Welsh to its fingertips" as well as the emphasis upon a "core creative team"; i.e., making this an authored text), clearly suggests that Thompson is aware of and is attempting to allay a concern that the national identity of the series would be somehow diminished or corrupted by its American involvement. As will become apparent, this attempt was a failure.

This study is drawn from my doctoral research, which consists of a close reading of the 41 televised episodes of the series as well as audience research; for the purposes of this paper, I shall focus primarily upon the audience. My anonymised sample consisted of 42 semi-structured interviews and 4 focus groups (totalling another 16 participants) from the US, Cana$\mathrm{da}$, the UK or transnationals, here defined as someone who was a long-term residence of any of those countries. The interviews were either by Skype or, more commonly, by email, and the focus groups were face-to-face. Because this paper focuses upon the negative audience response to series 4 , rather than a discussion of the series as a whole, my focus upon the interacting capitals allows me to touch on the various other elements with which this particular facet intersects. 


\section{Literature Review}

When analysing my empirical data, I utilised theories of discursive identity as related to globalisation and postmodernism (Straubhaar, 2007, 2008, 2012; Elliott, 2014), but by and large my focus will be on sociology, specifically Bourdieu. As Bennett et al. (2009) state, Bourdieu only dealt with television in two questions of his landmark study and due to the increasingly diverse forms of media that modern technology has spawned and the rise of the middle class omnivore (Skeggs, 2004; Bennett et al., 2009; Ng, 2010; Claessens \& Dhoest, 2010), his sharply differentiated notions of high and low class structures do not necessarily apply. As such, the questions of class he raised have been pushed to one side in contemporary media and cultural studies works. I would argue, as Bennett et al. (2009) and Skeggs (2004) do, that his work can be adapted to modern conditions, however. One of the main criticisms of Bourdieu, that his terms are too fluid (Robbins, 2000; Jenkins, 2002), actually allows this quite easily, as Pizania (2000) states: "Neither the fields nor capital and habitus remain static within the changing wider social field" (p. 158) (see Webb et al., 2002; Grenfell, 2004). Robbins (2000) likewise makes the point that global applicability (see Carey, 2005), and fluid terminology both derive ultimately from a predominantly social scientific positivist hegemony that still prizes the myth of objectivity and is just as much political as academic. Therefore, I would argue that Bourdieu's theories are flexible enough to be both adapted to modern television and new media, as well as applicable to other cultures.

Bourdieu's (1986) theories are predicated upon four sorts of capital operating within a culture. For the purposes of this paper, we can focus exclusively on cultural capital, though it is far from straightforward, in large part because it changes with the culture (see Skeggs, 2004). Bourdieu's (1986) original definition was "cultural capital, which is convertible, on certain conditions, into economic capital and may be institutionalized in the forms of educational qualifications." (p. 241). This narrow definition has been expanded in the intervening years, with definitions ranging from cultural "cultural forms of capital, the latter including both formal educational capital (degrees) and cultural knowledge acquired through family socialisation" and, following Hall, "'cultural capital', defined as 'knowledge 
of cultural codes'” (Claessens \& Dhoest, 2010, p. 69). Skeggs (2004), after summarising Bourdieu's statement quoted above, states that "Bourdieu defines cultural capital as high culture" (p. 16). Perhaps most interesting, however, is Bennett et al. (2009), who advocate the following:

First, [cultural capital] is attractive as a shorthand for the accumulation of resources that can be deployed for personal advantage. Second, it is versatile, with a capacity to capture features of educational institutions, the culture industries and the system of stratification in Western societies. Third, it has proved highly successful in the past in organising facts about unequal participation by different sections of the population in cultural activities that have been according differential value. Fourth, it has an integral connection in its theoretical corpus of origin with three other concepts of capital-economic, social and symbolic-which together can be combined to offer a complex account of the production and reproduction of social inequality. (pp. 257-258)

Thus, we have both a rationale and a coherent plan for the use of cultural capital in modern cultural studies.

Having discussed cultural capital generally, I shall now discuss two specific types that are relevant to this particular study. The first is cultural capital as it relates to fan cultures. There is no uniformly accepted term for this type of cultural capital, however. John Fiske (1987) uses the term popular cultural capital to mean cultural capital as recognised within fandom. Jancovich (2000, 2002), Skeggs (2004), Stenger (2006), Harris (1998), Brown (1998), and Smith (2011) all use the term fan subcultural capital for that, following Thornton (1995), who uses the term subcultural capital with regard to the capital of features of those involved in club cultures which, though lauded within the club culture are either ignored or stigmatised in the wider culture. I find problems with both of these terms. With regard to Fiske, the concept of the popular is very complex, and both his term and those based upon Thornton make it seem as though there is only one monolithic fandom that is a subculture of the commonly held culture (Hills, 2002; Booy, 2012; Zubernis \& Larsen, 2012). I therefore follow Matt Hills (2002) and use his term, fan cultural capital. This makes it clear that, though one can treat a fandom as a fan culture, it is not homogeneous. 
As Sandvoss (2003) shows in his work on sport fanbases, as Booy (2012) shows with his history of the Doctor Who fandom, and as Zubernis and Larsen (2012) show with their work on Supernatural, there are any number of subcultures within the overall fan culture. These subcultures not only have different relative measures of fan cultural capital, they can in fact be almost completely at odds with each other over the value of different fan practices as well as different readings of the fan text(s), paratexts, et cetera (Cubbison, 2012; Griffin \& Welch, 2013).

The second specific form of cultural capital to discuss is national cultural capital. This concept, rarely examined in works derived from Bourdieu, is discussed by Skeggs (2004) and Bennett et al. (2009), with the latter saying that "[...] 'practical nationality' can be conceived as a form of 'national cultural capital' that is invested in a sense of belonging" (p. 250). For his part, Skeggs (2004) states:

\begin{abstract}
Within the nation, national belonging constitutes the symbolic capital of the field, and to belong is to legitimate. [...] the aim of accumulating national capital is precisely to convert it into national belonging, to have accumulated national cultural capital recognised as legitimately national by the dominant cultural grouping. [...] It is not just the volume and composition of the right sort of cultural capital (for national belonging) but, rather, the right sort of capital depends on the processes by which it is acquired and displayed. [...] Bourdieu distinguishes between those who only have to be who they are as opposed to those who are what they do and, therefore, have to constantly prove that they are capable of carrying the signs and capital of national belonging. (p. 19)
\end{abstract}

Thus, for Skeggs and Bennett et al., national cultural capital is related to the psychological state of belonging and it is also performative, with Skeggs further explaining that the amount of required performativity varies based on how much cultural capital is embodied.

What is striking about both of these specific forms of cultural capital is that they have never been examined in combination. This is despite the strong connection some cult icons have with real life locations, e.g. Elvis with Graceland and both the Doctor and Sherlock Holmes with the UK/England 
(Rutherford, 2010; Green, 2010; Tulloch, 1995). I therefore will be taking as one of my primary research questions how these two cultural capitals interact. One can also take this to the level of regionalism; Welsh identity is itself fractious (Dicks, 2000; Kumar, 2003; McElroy, 2011; McElroy et al., 2010; Blandford \& Lacey, 2011). Although Tulloch (1995) notes that fans of the "classic" Doctor Who devalued American telefantasy in comparison with it (see Weissmann's 2012 work on the national imaginary), Sandvoss (2003) does discuss how football fandom is related to national identity, especially in the case of expatriates, and Booy (2012) gives a brief reference to British Doctor Who fans in the eighties who feel uncomfortable with some American-associated fan practices, none of these sorts of questions have been as yet theorised in-depth by academia. For my own work, I shall be following Couldry (2003) and Hills (2005), who have both suggested using Bourdieuian field theory to examine how subcultural symbolic capital can be accrued through the interplay of general media products and references with general media production (with Couldry using a centre-periphery model) and, more specifically, "ostentatiously intertextual displays of 'cultural capital' and 'subcultural capital' in horror" (Hills, 2005, pp. 166-167; see Beattie, 2014 on the Torchwood memorial in Cardiff Bay). This communication between fields by agents who move amongst them and the attendant, often disproportionate, effect shall be examined in my empirical data by looking at the interaction(s) between the fan and national cultural capital accrued by fan-agents and industrial-agents (often one and the same, e.g., Russell T. Davies) moving through the various fan and national fields.

As noted above, Torchwood's production history is a combination of British/Welsh, Canadian and American production partners. This is important because these particular national origins have a strongly interlinked and, in the case of British and American media, adversarial history. In her comprehensive study of the development of British, American and, as a mediator, Canadian, broadcasting, Michelle Hilmes (2012) notes that, though the respective industries are (and have been) complexly interlinked, British public service broadcasting (PSB) and American commercial TV have been embroiled in particular discourses that position them as direct opposites, i.e., "chaos and control" (Hilmes, 2012, p. 31). Writing of the early days of radio, Hilmes (2012) points out: 
Clearly, elements of British broadcasting later attributed to its public service function... actually precede the definition of a public service mission for this barely emergent medium, and stem instead from concerns of nationalism and the state, at this point focused on the economic and political: to prevent transnational companies and the troublesome Marconi from dominating radio development in Britain, to keep the practice of broadcasting from escaping into the general population as it had in the United States, and to placate powerful press interests and protect government revenues. Invocations of "American chaos" became increasingly critical in achieving these objectives. Between 1922, when the Company was formed, and 1926, when the BBC as a public corporation was established, the emphasis rested primarily on technological and economic definitions of "chaos"; after 1926, it was American cultural chaos that primarily concerned critics, a shift in definition stemming primarily from the efforts of John C. W. (soon to be Sir John) Reith. (p. 42)

This paragraph is worth analysing in depth, as it not only forms the foundation of the rest of Hilmes's book, but it is also the bedrock underlying much of the audience response in my research. What Hilmes has determined is that not only did ideas of American chaos and British control pre-date the PSB associations but Reith, later the first Director-General of the $\mathrm{BBC}$, actively and intentionally utilised and repurposed this discourse. Reith's association between the PSB BBC and art/culture and his setting it up against American culture, drawn from the earlier economic and political concerns and therefore focused upon connecting American media to commercialism, functions to not only make the two media appear distinct, but also mutually exclusive.

As is clear from the above, in addition to being opposites, this historical discourse also positions American media as having far lower cultural capital than its British counterpart. While I will discuss the Bourdieuian aspects below, what is important to note at this juncture is that this fallacious discourse is still very much in evidence in my audience research (see Porter, 2012; Derhy, 2013). This is contra Weissmann (2012), whose focus is upon "American" Quality Drama and, though it has multiple elements drawn from UK drama, “[...] how these discourses [of quality or 'good' television] shifted as American Quality Drama moved from 
its country of origin to the UK. Importantly, there it became known as American Quality Drama, suggesting a discursive interlinking of 'quality' and national origin" (p. 164, italics in original). The associations made by both academics and the audience with American and British media thus become relevant when examining the perceived changes between series 1 through 3 and series 4 through the interaction between fan and national cultural capitals.

\section{Analysis}

In terms of Torchwood series 4, one of the several ways of interpreting the negative fan response relates to the most common term used in the two works that discuss series 4 (Porter, 2012; Derhy, 2013) — that is to say, that it is Americanised. Neither work, however, interrogates that meaning, simply leaving it as self-explanatory. I have examined the concept in my empirical research; though there are a number of elements which constitute what my respondents considered Americanisation, they can all broadly be thought of as the series, in series 4, having increased its American national cultural capital at the expense of its British or Welsh national cultural capital. This change then interacted with the series' fan cultural capital in three main ways: intertexts, aesthetics, and perceived-authorship.

One of the main generators of meaning in telefantasy is the use of intertexts (Tulloch, 1990; Fiske, 1987). These can be either intradiegetic or interdiegetic, or, in other words, either generating meaning through self-referential means, as well as referencing other series or popular/common cultural signifiers in order to create polysemy and/or to increase their fan cultural capital. They can also be extradiegetic, meaning that they refer to paratexts in some way, thus generating meaning(s) for those familiar with said paratexts. The exact function of these intertexts varies, as does audience awareness and response. Hills (2002) points out that cult texts will play with their own norms and diegetic rules to reduce audience familiarity, whilst Nelson (2007) argues that, though some members of the audience will find pleasure in an intertext, others will not notice the intertext at all, potentially leading to different responses. These intertexts, 
however, can carry national identity connotations as well as generic or branding ones.

The main vehicle for increasing the series' fan cultural capital was via the use of intertexts; what existing analyses of Torchwood fail to discuss is the fact that the series was already so heavily influenced by American genre tropes as to be considered a glocalised text, though Short (2011) argues that the presence of the tropes denies the series any identity whatsoever. While I disagree with Short, these tropes are both legion and from both the US and the UK; Torchwood Magazine published a list of genre intertexts encapsulated within the first two series, including The X-Files (Carter, 1993; elements of the premise), Ghostbusters (Reitman, 1984; the vault being based upon the containment unit), Marvel comics ("the Hub" and "the Vault") and the Bond films, amongst others. In addition to being a melange of American and British telefantasy elements, it is worth noting that the American elements in particular are adjusted to fit the UK context. Showrunner for series 1 and 2 (and early consultant on series 4) Chris Chibnall noted in an interview that he felt Miracle Day (2011) had "[...] lost the show's essence" (Southall, 2013). He elaborated, saying:

When we were first talking about it, it was something a bit bolder, a bit cheekier. It may just come back to the fact that one of the great essences of Torchwood was taking those American tropes and doing them in Wales. In a way, that's what made Torchwood so brilliantly odd. Once you put it in California, it becomes more like other shows. (Southall, 2013, n.p.)

While Chibnall's statement clearly acknowledges the American elements present in the earlier series-and his subsequent success may have granted him the ability to be critical in this way - his note that the series loses its distinctiveness when displaced to the US is worth analysing in depth.

I would first argue that Chibnall's statement points to not only the first three series of Torchwood as being glocalised, in that American telefantasy tropes are somewhat altered to fit the UK and/or Wales, but also that this is to some extent subversive. In this context, this would mean that it is to some degree lampooning the tropes that are being glocalised (Rulyova, 
2007). Such subversion in Torchwood, instead of serving an ideological purpose per se would, I would argue, go more to the idea of the series playing with its own diegetic rules in order to avoid becoming formulaic, something common to cult telefantasy (see Hills, 2002) as well as postmodern television in general. It also acts as a way of strengthening its own brand by linking it to other quality/cult series brands (see Johnson, 2012; Johnson, 2013). But more relevant to the focus of this study is how this can be interpreted in terms of fan and national cultural capitals.

As discussed above, fan cultural capital and national cultural capital can both be interpreted as performative ways of "belonging" to a fandom or a national identity, respectively. What we see from this is that the blend of intertexts from both American and British telefantasy is a way of increasing the series'-and production team's - fan cultural capital. Including all of these homages shows that the series and those who produce it have a high degree of subcultural competency, to the extent that they can play with those tropes. It is not necessarily to the level of Rulyova's subversive glocalisation discussed above, but it is a strategy that I would argue is clearly being employed. By showing that the series' production team is made up of fans-helped in this case by Davies' own fan cultural capital having been well established by the time Torchwood began - it creates a sense that both production team and viewers belong to the same fandom. If we consider fandom as a sort of Heimat (Sandvoss, 2005) or at least an imagined community, then we can also see how this increase in the production team's fan cultural capital can create a sense of trust and/or obligation, especially when viewed in light of the historical discourses surrounding cult and mainstream being set up as opposites, with cult fans viewing themselves as elites, and the historically low cultural capital of cult media. Though both of these discourses are changing - and were likely fallacious to begin withthey are still ever-present. That sense of trust and/or obligation, however, can also, at least in part, account for the reactions of some fans to "having been lied to" by the production team with regard to series 4 (Porter, 2012; Derhy, 2013), which I will discuss further below.

In terms of national cultural capital, one could argue that the inclusion of the American telefantasy tropes should mean that the first three 
series were read as American or glocalised-American. I would argue, however, that the fan cultural capital, as well as the Welsh or British settings, production contexts and production team, including the cast, and the playful glocalisation - rather than a more serious or earnest attempt to glocalise-ameliorate this.

The case of series 4, however, is more complex, as it features a playfully glocalised series being glocalised again. In this instance, however, the second glocalisation is to the country from which it was initially glocalised. This disjuncture can perhaps be understood as contributing to the problematic reception of Miracle Day in that it exposed the small differences between American and British cultures by readapting something that had already been adapted (see Straubhaar, 2007). I would argue, however, that series 4 brings up a particular interaction between the two forms of capital. I would note that, in the first three series, reference to any telefantasy or cult media, regardless of perceived national origin, was interpreted as adding to the series' fan cultural capital. In series 4, however, because of the changes in production context and because of the perceived American cultural power in combination with associations of crassness or commercialism (e.g., the historical discourses), any reference to American-associated telefantasy of cult media was added not to fan cultural capital but American national cultural capital. Instead of being seen as performing fannishness, the references in series 4 were perceived as performing Americanness, and therefore contributed to the perceived Americanisation of the series.

As noted above when discussing the glocalised genre tropes, one of the main ways in which the Torchwood text was glocalised was in terms of both paratexts and intertexts (see Gray, 2010), which is the reason for my focus upon them. The difference between the two is sometimes blurred, especially with regard to Torchwood, but we can read Doctor Who as both paratext and intertext, in the sense that it both frames and interacts with the Torchwood text at different times, though not in a uniform way due to the different industrial contexts of both series (Garner, 2013). In both cases, however, Torchwood's link with the British—or, arguably, English—genre series par excellence does help to position the series as British, just as the 
BBC imprimatur and filming locations do (see Newman \& Levine, 2011, on the author functioning in this way). That said, the fact that Torchwood's metonym - here also relating to and evoking the series' brand, with Berger's (2010) note that metonyms are connotative and "resonate with what we already know" (p. 20) - has an American accent (though it is diegetically other) complicates this reading and can be interpreted as a glocalisation of either an American leader of a British genre team or as the inclusion of, or synthesis with, an American into a British genre series with the diegetic otherness ameliorating any concerns about American dominance. This can be read as supporting the idea that Welsh media, or British media, can "survive" the inclusion or manage the absorption of some American elements without losing "itself"; this again complicates the historical discourse around British versus American media whilst simultaneously denying the perception that there is either a recognised transnational genre or that there have been transferred elements of British and American media for decades.

This becomes more complicated still when discussing series 4, as having the metonym being American-accented would have operated against the clearly articulated industrial desire to keep the series positioned as Welsh-one can perhaps argue that the early inclusion of Gwen and Rhys in the first episode of series 4, as well as the focus upon their plotline was an attempt to ameliorate this by bringing Gwen in as co-metonym. Gwen's divisiveness as a character, however, operated against this.

Other intertexts include casting (Gray, 2010) and, I would argue, production team members as well. In both cases we can see both national identity and glocalisation at play. In series 1,2 and 3 most of the casting intertexts are to other British series - e.g., Gareth Thomas of Blakes 7 (Nation, 1978) in series 1, episode 3, Nerys Hughes of the The Liver Birds (Lane \& Taylor, 1969) in series 2, episode 9, Ruth Jones of Gavin and Stacey (Corden \& Jones, 2007) in series 2, episode 11, Peter Capaldi of The Thick of It (Iannucci, 2005) in series 3-one can also see the strong connections to Wales in many of those intertexts as well. In terms of the production team, of those who were not literally shared with Doctor Who and 
The Sarah Jane Adventures (Davies, 2007) there were intertexts made with P. J. Hammond, an English writer who is best known for Sapphire and Steel (Hammond, 1979), and Catherine Tregenna, a Welsh writer who had been an actress on Welsh-language soap opera Pobol Y Cwm (Hefin, 1974). Thus we can see the creation and maintenance of this national genre as well as sub-genres (e.g. British telefantasy).

That said, the major casting intertext in terms of genre was to do with casting James Marsters as Captain John Hart in series two. ${ }^{2}$ The American Marsters is best known for playing the English vampire Spike in Buffy the Vampire Slayer (Whedon, 1997) and Angel (Whedon \& Greenwalt, 1999), two highly successful American genre series (see Derhy, 2013, for Davies' pre-existing interest in these series), which, taken together, are commonly referred to as the Whedonverse. Though Spike spoke with a diegetically-noted affected working class London accent and shared his look with Billy Idol, John Hart used a blended RP and American accent and had dark hair. And, though Abbott (2013) argues that Marsters's casting reinforces her reading of Jack as an exacerbated analogue to Angel due to the dynamic between John and Jack mimicking that of Spike and Angel, I would argue that the differences between the characters' looks and the playful way in which verbal intertexts relate to both Buffy — but not Spike—and Firefly (Whedon, 2002) a Whedonverse series in which Marsters never appeared, suggest that the intertexts connecting Torchwood to the (fan) cultural capital of the Whedonverse were designed to cater to the new or crossover audience Marsters would bring. More relevant to this study, however, it makes clear some of the US genre tropes which the series has glocalised to the UK. These include elements of costuming and aesthetics, as well as the many genre tropes listed above.

Thus, what we see in the first three series is a text that blends both "native" British tropes and playfully glocalises American ones. That said, the series is still strongly positioned within a Welsh national imaginary due to a combination of industrial factors, as noted above.

2 In episode 1 of Torchwood Declassified, Russell T. Davies states that, after James Marsters expressed an interest in appearing the series, the nascent role of Captain John Hart was written specifically for him. 
In series four, however, we take this glocalised text and glocalise it again, this time back to the US. In terms of casting, very likely for legal/industrial reasons, ${ }^{3}$ most casting intertexts relate to American genre series. These include Bill Pullman (Spaceballs, Brooks, 1987; Independence Day, Devlin \& Emmerich, 1996), John de Lancie (Star Trek: The Next Generation, Roddenberry, 1987; Star Trek: Deep Space Nine, Berman, 1993; Star Trek: Voyager, Berman et al., 1995; Stargate SG-1, Wright \& Cooper, 1997), Nana Visitor (Star Trek: Deep Space Nine), C. Thomas Howell (The Hitcher, Bombyk \& Harmon, 1986; Red Dawn, Milius, 1984), Ernie Hudson (Ghostbusters, Reitman, 1984; Ghostbusters 2, Reitman, 1989), Wayne Knight (Jurassic Park, Spielberg, 1993; $3^{\text {rd }}$ Rock from the Sun, Lithgow et al., 1996), ${ }^{4}$ Robin Sachs (Buffy the Vampire Slayer, Whedon, 1997; Babylon 5, Straczynski, 1993; Galaxy Quest, Parisot, 1999), and Dichen Lachman (Dollhouse, Whedon, 2009). ${ }^{5}$ One cannot help but notice the intertexts with the Whedonverse that are also extant (and enhanced); production team intertexts reinforce this as well, as Jane Espenson of Buffy the Vampire Slayer and Firefly, amongst other Whedon series-and Battlestar Galactica (Larson \& Moore, 2004) and Caprica (Aubuchon \& Moore, 2009), of which she was showrunner in her own right-was a co-executive producer. She, along with costume designer Shawna Trpcic (see Warner, 2014, on costumers and fanbase) and, arguably producer Kelly A. Manners (Buffy the Vampire Slayer, Angel, Dollhouse), all carry forward the Whedonverse "brand" onto series 4. John Shiban, of The X-Files, Enterprise (Berman \& Braga, 2001), Supernatural (Kripke, 2005), and Breaking Bad (Gilligan, 2008) carries similar connotations, especially in terms of horror and conspiracy. Doris Egan also wrote for Supernatural and has written multiple sf/ fantasy novels ("Doris Egan", n. d.), but most applicably to Miracle Day is her strong association with US medical drama House (Shore, 2004, starring English actor Hugh Laurie). Her episode (4.2) is the most heavily medical of all ten episodes and her involvement in the series ties Torchwood: Mir-

3 That is to say, reasons relating to tax and visa requirements that would predispose productions to hire Americans (or those of dual nationality and/or permanent residents) over bringing in people from other nationalities.

4 Though he is, I acknowledge, best known for Seinfeld (David \& Seinfeld, 1989).

5 Eliza Dushku (Buffy the Vampire Slayer, Angel, Dollhouse) also appeared in the 'moving comic' Web of Lies. 
acle Day (or TW: $M D$, evoking the idea of a medical doctor) carries connotations of both genre and medical drama with strongly drawn, morally grey characters. This connection to American medical drama also relates to the casting intertext of Mekhi Phifer as Rex; though playing a CIA agent in Miracle Day he is best known for playing Dr Greg Pratt in ER (Crichton, 1994). Thus, we can see that, in terms of intertexts, series four was almost exclusively linked to the American genre, but blended both telefantasy and medical drama subgenres. This intertextual casting can also be interpreted as a way of acquiring a new audience; both series 4 and series 2 have done this intertextually (and both involving the Whedonverse) but only series four's efforts are attributed to Americanisation. I would argue this is due to Marsters' blended national identity connotations, whereas the intertexts in series 4 were far more Americanocentric and, due to the rest of the production context, were folded in with those discourses. Thus, they contributed more to American national cultural capital than fan cultural capital, meaning that, instead of being seen as the series performing fannishness, it was seen as performing Americanness.

In addition to and complementary with intertexts as generators of both fan and national cultural capital, we can also see the aesthetics of the series contributing to both as well. We can view this both in terms of a (fallacious) national style, here linked to the national imaginary, and the use of national identity signifiers in the series itself.

When asked to define what was meant by Americanised, the most common phrases referred to aesthetics (e.g., glossy, shiny, inauthentic) or the aesthetics of the cast (e.g., unrealistically good-looking) as well as the changes in both production location and the setting. Characterisation, considered "poor" (see Porter, 2012; Derhy, 2013, who note the same), is also attributed to being Americanised as are the perceived increase in quantity or gratuitousness of the violence and sex. That it is quantity, especially with the violence (several respondents were also upset that they felt Jack had been changed from omnisexual to gay), is important to note, as several respondents did acknowledge that violence, stunts and explosions had been 
present all along in the series. They felt that it had increased somehow and attributed that to a perceived Americanness. While a side-by-side comparison between the pilot of Torchwood (1.1) and the first episode of series 4 (4.1) reveals that there are significant aesthetic differences, (e.g., changes in costuming, casting, setting and 1.1's horror versus 4.1's action-adventure style), what the response can indicate is that series 4 , on the whole, performed a strongly (perceived) American national cultural capital. This is in direct contrast to earlier series, which respondents and participants interpreted as performing a strongly Welsh (or sometimes British) national cultural capital.

There are, clearly, a number of issues to unpack in this. Due to restrictions of space, I shall primarily touch on them here with regard to their intersection with fan and national cultural capitals.

The first thing to note is the presence of what Weissmann (2012) views as something akin to a genre associated with national origin, also sometimes called the "national imaginary" after Tulloch (1995). Weissmann (2012) argues that, as is generally the case with genre (e.g., Mittell, 2004, 2008), the national imaginary is discursively created by the industry as well as by audiences in which series that are, though in most other ways dissimilar, compared and contrasted against each other. In this paper I will focus on the audience's construction of such a pseudo-genre, as this was explicitly the case in the London focus group, in which participants compared what they perceived as the relative Welshnesses of Torchwood with two other series-Anglophone, Essex-and-Cardiff-set rom-com, Gavin \& Stacey, and Welsh-language soap opera, Pobol Y Cwm. While the Welsh language as signifier of Welsh culture or Welshness is a very commonly-held belief (see, for instance, Griffiths, 1996 and Medhurst, 2010), that Anglophone Torchwood has always been somehow "less" Welsh than the equally Anglophone, frequently England-set Gavin \& Stacey — before series three, Torchwood had two scenes outside of Wales and series three still took place (and was filmed) primarily in South Wales_-shows that there is a distinct hierarchy involved. Moving the series to the US for most filming and much 
of the setting seemed also to diminish the perceived Welshness. That said, perhaps unsurprisingly given the fractiousness of Welsh identity (see Kumar, 2003), it can in some instances be expressed as "not-England," as well as the essentialist idea that Britishness cannot encompass both Welshness and Englishness (see Miller, 1995). This also corresponds to Weissmann's (2012) argument that national and transnational television discourses are almost always read in terms of power relations; in two focus groups (Cardiff and Aberystwyth), participants expressed doubt as to whether Cardiff itself was Welsh-either in the sense of an Augean (2008) non-place or in the sense that it was an identity in and of itself-as well as dismay that there was no use of Welsh mythology or history (Cardiff, see Porter, 2011), no attempt to leave South Wales (Aberystwyth) and only one sentence of Welsh (Aberystwyth). Though none of the participants argued that the lack of Welsh mythology and history relates to industrial contexts, that is, I would argue, implicit in their discussion of overall Welsh and English culture; the Aberystwyth focus group (made up of people with a Media Studies background) did take into account the perceived difficulty of selling such a series transnationally_Hinterland/Y Gwyll (Talfan \& Thomas, 2013) not yet having aired at the time the focus group was held-but it was still subordinate to perceived primacy of narrative considerations. What is most important here is that, though participants and respondents all read a slightly different iteration of Welshness or Britishness, that they perceived a discursive identity (which here means the national imaginary) in an essentialist manner. ${ }^{6}$ Both shows how complex the interactions of various capitals can be as well as reinforcing the idea that, as my study found, academic theory which associates Americanness with quality drama and empirical data which express the historical view of Britishness equalling quality do not always correspond.

The aural and visual signifiers of national identity, however, each of which carries national cultural capital, were also noted by respondents as

6 e.g. quantifiable and zero sum, that is, Welshness or Britishness could neither be dynamic enough to allow for some American elements within it or vice versa and that the amount was fixed; in other words, if American national cultural capital increased, for the respondents it must do so at the expense of the Welsh or British national cultural capital 
being a way in which national identity or identities were performed. These included accents, language (one line of spoken Welsh in 3.5 and multiple instances of written Welsh on signage), props and set decoration as well as exteriors, especially identifiable areas (e.g. the Millennium Centre). For series 4, attribution of an American national identity and associated national cultural capital follows along much the same lines as attribution of Welsh identity for the first three series in terms of textual elements. The physical filming and diegetic locations were mostly in the US, with Welsh exteriors shot for Wales and various areas in and around Los Angeles standing in for multiple diegetic locations. American characters populated the diegetic world and all respondents were able to identify a change in the mise-en-scène. Though few were able to articulate the visual changes, most respondents strongly responded to the change in aural environment commensurate with the Welsh and other British accents from the first three series having been replaced by Americans. This was particularly disliked by respondents, who felt that this aural change meant that Jack became less distinct. The loss of distinction across the board during series 4 can be tied to quality discourses as well as concerns of McTelevision/Europudding, which were commonly associated with regard to discourses about globalised television, especially if co-produced by the US (e.g., Steemers, 2004; Born, 2004; Selznick, 2008, 2010; Straubhaar, 2007; Weissmann, 2012), which were themselves related to the historical lack of cultural capital of American television.

As noted above, I have decided to use the term fan cultural capital (cf. Hills, 2002), as it argues for fan culture without implying that the culture is homogeneous. National cultural capital, on the other hand, is performative and related to the idea of belonging (Skeggs, 2004; Bennett et al., 2009), and the amount of required performativity varies with regard to how much (usually embodied) cultural capital is present. Because a TV text does not have a literal body but is perceived as expressing its national identity through its aesthetics and narrative elements (e.g., banal diegetic nationalism, which I have adapted from Billig, 1995), I would argue that these elements analogise to embodied characteristics of people and would therefore fit. 
One of the most common associations that respondents and focus group participants made was between the move to the US, the (perceived) intent of which involved acquiring a more mainstream audience and a (perceived) desire to make money or otherwise becoming more commercialised. This certainly expresses the historical US vs. UK media discourses, but it can also suggest that Starz and American television both lack fan cultural capital because of the (fallacious) association between fan activities and doing things for the "love" of it, e.g., "[...] fans' perception that what they do is explicitly anticommercial prevents them from considering what they do as warranting pay. Subcultures often organise in opposition to social norms..." (de Kosnik, 2013, p. 108; see Jenkins, 1992; Pearson, 2010; Zubernis \& Larsen, 2012; Hills, 2002; see Hendry, 2000 for related associations to art).

In terms of national cultural capital, however, we can to some extent tie this in with Weissmann's (2012) national imaginary; what I would address here, however, is the required performativity Skeggs (2004) discusses. Because of the new production context for series four, which had been widely known and already read negatively by fans even before the series aired, the text would need to perform its Welshness or Britishness very strongly to compete with (or complement or absorb) its perceived Americanness. Because the number of American textual elements added (e.g., characters, setting, casting, production context) was perceived to "outnumber the Welsh or British" (i.e. my interview respondent Shary's [2013] assertion that the Welsh elements were "tacked on"), the series was perceived to "belong" to the US. The American national cultural capital outperformed the Welsh or British and, because of the (perceived) association between American television and "selling out," or a lack of fan cultural capital in this context, the devalued American national cultural capital seemed to devalue the fourth series.

Thus, it is clear that the association between American media and commercialism or "crassness" decreased the amount of fan cultural capital of the series (e.g., "selling out," as focus group participant Oscar put it). Consequently, as the American content (or perceived-American con- 
tent) increased via the change in setting, production locations and cast, the American national cultural capital increased whilst the perceived Welsh or British national cultural capital — and its association with art or culture via the BBC's public service broadcast history-decreased. This is only reinforced when examining the fan and national cultural capitals of the series in relation to authorship.

According to Weissmann (2012), the author figure is an important part of the "national fantasy" (see Jancovich, 2002). Though Barthes (mostly) killed the author almost half a century ago (1972), in fan discourse, generally, and in my research, in particular, the author figure-here called the showrunner-is still very visible. Despite being a discursive construction and despite the fact that fans are very aware that television is a collaborative effort, to the point that people working in both above- and belowthe-line positions can have their own fanbase (see Warner, 2014; Gray, 2010), the author function is still prevalent; this broadly follows Hills (2013), who focuses specifically on Torchwood and its author(s). First noting that the series is sometimes considered fragmented and authorless, he argues that the series has

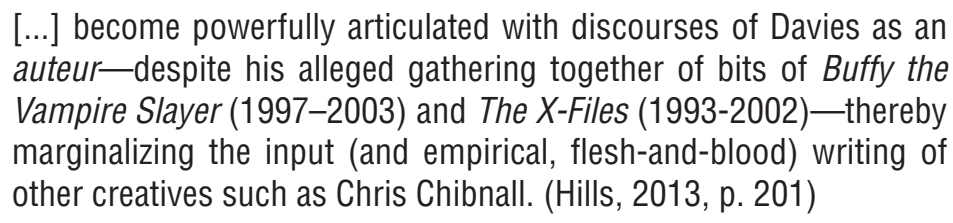

In terms of audience response, Torchwood, like parent series Doctor Who, is not only read as a strongly authored text, but authorship is focused almost exclusively upon Davies. Respondents routinely refer to Davies's intentions as author as well as attributing at least some of the Welshness of the series to him, and occasionally the rest of the production team. In this view, the series can almost be understood as an extension of the author figure - his brain or will or even be autobiographical—which means that it can be argued that the national identity embodied by the showrunner (Newman \& Levine, 2011) is similarly embodied by and within the series itself. This occurs despite all respondents expressing an awareness that television is collaborative (Sender, 2012). 
Perhaps most suggestive of the promotion of author/showrunner-as-brand, and its attendant national identity elements is that only two of my respondents (Canadian Media Studies student Paloma and historian and Doctor Who scholar William) mentioned Chris Chibnall, who was the day-to-day showrunner during the first two series. Chibnall also contributed four scripts in series 1 and four more in series 2, comprising $30.8 \%$ of the "classic" corpus. Davies, though the creator and ostensible showrunner, wrote only one episode, or $3.8 \%$. The importance of this point is that Chibnall is English, not Welsh. This means that all of the embodied Welshness Davies carries still is associated with the series despite Davies's own admitted lack of attention to the series (Hills, 2013). This is most clearly illustrated by respondent Joyce, who, when asked if she read the series as particularly Welsh, replied:

And since Torchwood's whole point is to protect Great Britain from outside influence again it might be going back to the immigration issue, it might be going back to um, at least in some ways, dealing with English oppression, but I don't know how many of the writers are English as opposed to Welsh. [...] Because a lot of that expression of oppression would come out of a Welsh writer I think without them thinking too much about it. You know, they're not going to explicitly say 'this is really about how much we hate England' or something, but an English writer probably wouldn't think of that. Um, instead it would just be a show about aliens and this is how we deal with them. I don't know. (Joyce, 2013)

Joyce is thus aware that there are multiple members of the writing staff but assumes not only that an English writer would not (and could not) write for Welsh characters in the same way that Welsh writers would or could, but also that the proportion of Welsh to English writers can similarly quantify the amount of level of "Welshness" of the series. This is both a clear example of the idea that an author's work is metatextually autobiographical (Newman \& Levine, 2011) as well as a clearly essentialist discourse similar to what I have discussed elsewhere.

Davies's embodied Welsh cultural capital also impacted the reception of series 4. Lisa views the American culture shown as Davies's “ide- 
ology," while Victor reads the representation of Welshness as a whole as: "[...] what [Davies] thinks Wales is rather than what the history books would say Wales is." One can then ask, however, if Davies's Welsh national identity is transferred onto the text, then how can the text still be considered American? In the Aberystwyth Focus Group, it was noted by Oscar that Davies was said to have "made... promises" about keeping the show Welsh and it not becoming American. That statement, in addition to clearly expressing national imaginaries, also shows much about the author-fan relationship. Specifically, it focuses upon an implied social contract between author figure and fan (e.g., Sandvoss's 2005 idea of fandom as Heimat), reinforced by Davies's positioning as a (classic) Doctor Who fan. Thus, as his own fan cultural capital (i.e., perceived as working on the series "for love") was diminished by perceived association with Americanness (i.e. perceived commercialism) these promises, as Oscar terms them, were "made" in order to try to retain that fan cultural capital for himself and the series. When the series aired and the focus group felt that the Welshness was inadequately performed by the series, that implied social contract based upon Davies and the fanbase being perceived as members of the same fan community was broken. Thus, the interaction between Davies's perceived fan and national cultural capitals and the perceived fan and national cultural capitals of the series itself can be interpreted as playing a major role in the negative reception of series four.

\section{Conclusion}

In this paper, I have focused upon one particular factor amongst many competing ones-the interaction between fan and national cultural capitals, with regard to the success or failure of glocalised (or reglocalised) media texts. I have defined both fan and national cultural capitals and applied them to contemporary media theory with regard to national imaginaries, authorship and representation as well as showing their various interactions through the use of examples drawn from my empirical research. I have also shown the value of studying national cultural capital, despite it being one of the less commonly studied aspects of Bourdieu; it is also useful in helping to interpret the ill-defined term Americanisation that has been used uncritically by academics and fans alike with regard to Torchwood. 
More specifically, I have illustrated how at least some elements of the series were first subversively glocalised from primarily the US to Wales and how that functioned to increase the series' fan cultural capital. When the series was reglocalised to the US, the combination of changes in the production context (location, cast, crew, et cetera) and the historical but still present associations relating Americanness to crassness and commercialisation, this meant that any intertext to an American-associated telefantasy or cult media product (including via casting and production team members) were read as increasing the American national cultural capital instead of increasing the fan cultural capital. Despite Davies's Welsh cultural capital conveying Welshness onto the series, his perceived loss of fan cultural capital as a direct result of and in combination with the series' perceived increase in American cultural capital for series 4 devalued the series' Welshness to the point that, despite Davies's perceived authorship, the BBC's best efforts and the Welsh-related plot and character elements, the audience did not perceive the series as performing its Welshness to the expected or desired amount.

With regard to future directions, examination of both the ways in which fan and national cultural capitals of both series and characters within series are expressed and ways in which they are interpreted will be useful to other scholars looking at the reception of transnational co-productions, in general, and representation and reception, in particular. Given the increasing focus onto narrowcasting and developing a loyal audience as well as the "new normal" (Hilmes, 2014) of global co-productions, the interaction of these two capitals are likely to continue to be relevant in regards to whether a given series is "adopted" by a country or countries, or perceived as an epic fail.

\section{References}

Aubuchon, R. (Writer), \& Moore, R. M. (Executive Producer). (2009). Caprica. NBCUniversal Television Distribution.

Auge, M. (2008). Non-places: An introduction to supermodernity (J. Howe, Trans.). London: Verso. 
Barthes, R. (1972). Mythologies (A. Lavers, Trans.). London: Paladin.

Beattie, M. (2014). A most peculiar memorial: Cultural heritage and fiction. In J. Schofield (Ed.), Who needs experts? Counter-mapping cultural heritage (pp. 215-224). Aldershot: Ashgate.

Beckerman, S. (Producer), \& Milius, J. (Director). (1984). Red dawn [Motion Picture]. United States: United Artists/Valkyrie Films.

Bennett, T., Savage, M., Silva, E., Warde, A., Gayo-Cal, M. \& Wright, D. (2009). Culture, class, distinction. London: Routledge.

Berger, R. (2010). Screwing aliens and screwing with the alien: Torchwood slashes the doctor. In A. Ireland (Ed.), Illuminating Torchwood: Essays on narrative, character and sexuality in the BBC series (p. 6675). London: McFarland.

Berman, R. (Executive Producer) \& Piller, M. (Showrunner). (1993). Star trek: Deep space nine [Television series]. Syndicated.

Berman, R. (Executive Producer) \& Braga, B. (Showrunner). (2001). Enterprise [Television series]. Los Angeles, California: UPN.

Billig, M. (1995). Banal nationalism. London: Sage.

Berman, R. (Executive Producer), Piller, M. \& Taylor, J. (Showrunners). (1995). Star trek: Voyager [Television series]. Los Angeles, California: UPN.

Blandford, S. \& Lacey, S. (2011). Screening Wales: Portrayal, representation and identity: A case study. Critical Studies in Television, 6(2), 1-12.

Bombyk, D. (Producer) \& Harmon, R. (Director). (1986). The hitcher [Motion picture]. United States: HBO Pictures/Silver Screen Partners.

Booy, M. (2012). Love and monsters: The Doctor Who experience, 1979 to the present. London: IB Tauris. 
Born, G. (2004). Uncertain vision: Birt, Dyke and the reinvention of the BBC. London: Vintage.

Bourdieu, P. (1986). The forms of capital. In J. Richardson (Ed.), Handbook of theory and research for the sociology of education (pp. 241258). New York: Greenwood.

Brooks, M. (Director). (1987). Spaceballs [Television series]. Beverly Hills, California: MGM.

Brown, A. (1998). United we stand: Some problems with fan democracy. In A. Brown (Ed.), Fanatics! Power, identity \& fandom in football (pp. 50-68). London: Routledge.

Carey, J. (2005). What good are the arts? London: Faber and Faber.

Carter, C. (Executive Producer). (1993). The X-Files [Television series]. Los Angeles, California: Fox.

Claessens, N. \& Dhoest, A. (2010). Comedy taste: Highbrow/lowbrow comedy and cultural capital. Participations, 7(1), 49-72.

Corden, J. (Writer), \& Jones, R. (Writer). (2007). Gavin \& Stacey [Television series]. United Kingdom: BBC3/BBC1.

Couldry, N. (2003, May). Television and the myth of the mediated centre: Time for a paradigm shift in television studies? Presentation at the Media in Transition 3 conference held in MIT, Boston, MA.

Crichton, M. (Executive Producer). (1994). ER [Television series]. New York City, New York: NBC.

Cubbison, L. (2012). Russell T. Davies, “Nine Hysterical Women,” and the death of Ianto Jones. In B. T. Williams \& A. A. Zenger (Eds.), New media literacies and participatory popular cultures across borders (pp. 135-150). London: Routledge. 
David, L. (Executive Producer) \& Seinfeld, J. (Executive Producer). (1989). Seinfeld [Television series]. New York City, NY: NBC.

Davies, R. T. (Writer) \& Kelly, B. (Director). (2006). Everything changes [Television series episode]. In R. T. Davies (Executive Producer), Torchwood. United Kingdom: BBC2/BBC3.

Davies, R. T. (Executive Producer). (2007). The Sarah Jane adventures [Television series]. United Kingdom: CBBC.

Davies, R. T. (Executive Producer). (2009). Torchwood: Children of Earth [Television series]. United Kingdom: BBC1.

Davies, R. T. (Executive Producer). (2011). Torchwood: Miracle day [Television series] Torchwood. Meridian, CO: Starz.

de Kosnik, A. (2013). Fandom as free labour. In T. Scholz (Ed.), Digital labor: The Internet as playground and factory (pp. 98-111). London: Routledge.

Derhy, B. W. L. (2013). Cult yet? The 'miracle' of internationalisation. In R. Williams (Ed.), Torchwood declassified: Investigating mainstream cult television (pp. 51-64). London: IB Tauris.

Devlin, D. (Writer) \& Emmerich, R. (Director). (1996). Independence day [Motion picture]. United States: Centropolis Entertainment.

Dicks, B. (2000). Heritage, place and community. Cardiff: University of Wales Press.

Doris Egan. (n. d.). Retrieved from http://www.imdb.com/name/ nm0250668/?ref_=nv_sr_3

Elliott, A. (2014). Concepts of the self, $3^{\text {rd }}$ Ed. Cambridge: Polity.

Fiske, J. (1987). Television cultures. London: Routledge. 
Ford, W. (Writer) \& Way, A. (Director). (2008). Something borrowed [Television series episode]. In R. T. Davies (Executive Producer), Torchwood. United Kingdom: BBC2.

Garner, R. P. (2013). Access denied? Negotiating public service and commercial tensions through Torchwood's intertextual barricade. In R. Williams (Ed.), Torchwood declassified: Investigating mainstream cult television (pp. 13-32). London: IB Tauris.

Gilligan, V. (Executive Producer). (2008). Breaking bad [Television series]. New York City, NY: AMC.

Gray, J. (2010). Show sold separately: Promos, spoilers, and other media paratexts. New York City: NYU Press.

Green, J. P. (2010). The (re)generation game: Doctor Who and the changing faces of heroism. In R. Garner, M. Beattie \& U. McCormack (Eds.), Impossible worlds, impossible things: Cultural perspectives on Doctor Who, Torchwood and The Sarah Jane Adventures (pp. 3-24). Newcastle: CSP.

Grenfell, M. (2004). Pierre Bourdieu: Agent provocateur. London: Continuum.

Griffin, M. \& Welch, R. (2013). Crisis of authority/authoring crisis: Decision and power in Torchwood: Children of Earth. In R. Williams (Ed.), Torchwood declassified: Investigating mainstream cult television (pp. 104-119). London: IB Tauris.

Griffiths, A. (1996). Ethnography and the politics of audience research. In P. Crawford \& S. Hafsteinsson (Eds.), The construction of the viewer (pp. 47-68). Hojbjerg: Intervention.

Hammond, P. J. (Writer). (1979). Sapphire \& steel [Television series]. United Kingdom: ITV. 
Hammond, P. J. (Writer) \& Bassett, J. F. (Director). (2008). From out of the rain [Television series episode]. In R. T. Davies (Executive Producer), Torchwood. United Kingdom: BBC2.

Hammond, P. J. (Writer) \& Troughton, A. (Director). (2006). Small worlds [Television series episode]. In R. T. Davies (Executive Producer), Torchwood. United Kingdom: BBC2/BBC3.

Harris, C. (1998). A sociology of television fandom. In C. Harris \& A. Alexander (Eds.), Theorising fandom (pp. 41-52). Cresskill: Hampton Press.

Hefin, J. (Executive Producer). (1974). Pobol y Cwm [Television series]. Wales: BBC Wales/S4C.

Hendry, J. (2000). The orient strikes back. London: Bloomsbury.

Hills, M. (2002). Fan cultures. London: Routledge.

Hills, M. (2005). The pleasures of horror. London: Continuum.

Hills, M. (2013). From Chris Chibnall to Fox: Torchwood's marginalised authors and counter-discourses of TV authorship. In J. Gray \& D. Johnson (Eds.), A companion to media authorship (pp. 200-220). Chichester: Wiley and Sons.

Hilmes, M. (2012). Network nations: A transnational history of British and American broadcasting. London: Routledge.

Hilmes, M. (2014). Transnational TV: What do we mean by "co-production," anymore? Media Industries Journal, 1(2). Available from http://www.mediaindustriesjournal.org/index.php/mij

Iannucci, A. (Executive Producer). (2005). The thick of it [Television series]. United Kingdom: BBC4/BBC2. 
James, G. (2013). “Cool but high quality”: Torchwood, BBC America and transatlantic branding, 1998-2011. In R. Williams (Ed.), Torchwood declassified: Investigating mainstream cult television (pp. 3350). London: IB Tauris.

Jancovich, M. (2002). Genre and the audience: Genre classifications and cultural distinctions in the mediation of The Silence of the Lambs. In M. Jancovich (Ed.), Horror, the film reader (pp. 151-161). London: Routledge.

Jenkins, H. (1992). Textual poachers: Television fans and participatory culture. London: Routledge.

Jenkins, R. (2002). Pierre Bourdieu: Revised edition. London: Routledge.

Johnson, C. (2012). Branding television. London: Commedia.

Johnson, D. (2013). Media franchising: Creative licence and collaboration in the culture industries. New York City: NYU Press.

Kripke, E. (Executive Producer). (2005). Supernatural [Television series]. Burbank, California: The CW.

Kumar, K. (2003). The making of English national identity. Cambridge: CUP.

Lacey, S. (2013). "When you see Cardiff on film, it looks like LA" (John Barrowman): Space, genre and realism in Torchwood. In R. Williams (Ed.), Torchwood declassified: Investigating mainstream cult television (pp. 137-153). London: IB Tauris.

Lane, C., \& Taylor, M. (1969). The liver birds [Television series]. United Kingdom: BBC1.

Larson, G. A. (Executive Producer) \& Moore, R. M. (Executive Producer). (2004). Battlestar galactica [Television series]. NY City, New York: Sci-Fi Channel. 
Lithgow, J., Turner, B. \& Turner, T. (1996). $3^{\text {rd }}$ rock from the sun [Television series]. New York City, NY: NBC.

McElroy, R. et al. (2010). Executive summary of the landmark television survey. Available from http://culture.research.southwales.ac.uk/ news/en $/ 2010 / \mathrm{mar} / 15 /$ screening-nation-wales-and-landmarktelevision-rep/

McElroy, R. (2011). "Putting the landmark back into television": Producing place and cultural value in Cardiff. Place branding and public diplomacy, 7(3), 175-184.

Medhurst, J. (2010). A history of independent television in Wales. Cardiff: University of Wales Press.

Milius, J. (Director). (1984). Red dawn [Motion Picture]. United States: United Artists/Valkyrie Films.

Miller, D. (1995). On nationality. Oxford: Clarendon.

Mittell, J. (2004). Genre and television: From cop shows to cartoons in American culture. New York: Routledge.

Mittell, J. (2008). Genre study—beyond the text. In G. Creeber (Ed.), The television genre book, $2^{\text {nd }}$ Ed (pp. 9-13). Houndsmills: Palgrave MacMillan.

Nation, T. (Executive Producer). (1978). Blakes 7 [Television series]. United Kingdom: BBC1.

Nelson, R. (2007). State of play: Contemporary 'high end' TV drama. Manchester: Manchester University Press.

Newman, M. Z. \& Levine, E. (2011). Legitimating television: Media convergence and cultural status. London: Routledge. 
Newman, S., Webber, C. E. \& Wilson, D. (Executive Producers). (1963). Doctor who [Television series]. United Kingdom: BBC1.

$\mathrm{Ng}$, E. (2010). Telling tastes: (Re)producing distinction in popular media studies. Flow TV, 13. Retrieved from http://flowtv.org/2010/12/ telling-tastes/

Parisot, D. (1999). Galaxy quest [Motion picture]. United States: DreamWorks SKG/Gran Via Productions.

Pearson, R. (2010). Fandom in the digital era. Popular Communication: The International Journal of Media and Culture, 8(1), 84-95.

Pizania, C. (2000). Habitus revisited: Notes and queries from the field. In N. Brown \& I. Szeman (Eds.), Pierre Bourdieu: Fieldwork in culture (pp. 145-164). Lanham: Rowan and Littlefield.

Porter, L. (2011). Torchwood's "spooky-dos": A popular culture perspective on Celtic mythology. In A. Becker (Ed.), Welsh mythology and folklore in popular culture (pp. 140-159). Jefferson: McFarland.

Porter, L. (2012). The Doctor Who franchise: American influence, fan culture and the spinoffs. Jefferson: McFarland.

Raynor, H. (Writer) \& Teague, C. (Director). (2006). The ghost machine [Television series episode]. In R. T. Davies (Executive Producer), Torchwood. United Kingdom: BBC2/BBC3.

Reitman, I. (Director). (1984). Ghostbusters [Motion picture]. United States: Black Rhino/Delphi Productions.

Reitman, I. (Director). (1989). Ghostbusters 2 [Motion picture]. United States: Columbia Pictures.

Robbins, D. (2000). Bourdieu \& culture. London: Sage. 
Roddenberry, G. (Executive Producer). (1987). Star trek: The next generation [Television series]. Syndicated.

Rulyova, N. (2007). Domesticating the western format on Russian TV: Subversive glocalisation in the game show Pole Chudes (the field of miracles). Europe-Asia Studies, 59(8), 1367-1386.

Rutherford, A. (2010). Doctor Who slays St George. The Guardian. Retrieved from http://www.guardian.co.uk/commentisfree/belief/2010/apr/21/st-george-patron-saint

Sandvoss, C. (2003). A game of two halves: Football fandom, television and globalisation. London: Routledge.

Sandvoss, C. (2005). Fans: The mirror of consumption. Cambridge: Polity.

Selznick, B. (2008). Global television: Co-producing culture. Philadelphia: Temple University Press.

Selznick, B. (2010). Rebooting and rebranding: The changing brands of Doctor Who's britishness. In C. Hansen (Ed.), Ruminations, peregrinations, and regenerations: A critical approach to Doctor Who (pp. 68-84). Newcastle: CSP.

Sender. K. (2012). The makeover: Reality television and reflexive audiences. London: NYU Press.

Shore, D. (Executive Producer). (2004). House [Television series]. Los Angeles, CA: Fox.

Short, S. (2011). Cult telefantasy series: A critical analysis of The Prisoner, Twin Peaks, the X-Files, Buffy the Vampire Slayer, Lost, Heroes, Doctor Who and Star Trek. Jefferson, N.C: McFarland.

Skeggs, B. (2004). Class, self, culture. London: Routledge. 
Smith, J. (2011). Withnail and us: Cult films and film cults in British cinema. London: IB Tauris.

Southall, J. D. (2013). Interview: Chris Chibnall Part 1 Torchwood. Starburst Magazine. Retrieved from http://www.starburstmagazine.com/features/interviews/4568-interview-chris-chibnall-part-1-torchwood

Spielberg, S. (Director). (1993). Jurassic Park [Motion picture]. United States: Amblin Entertainment/Legendary Pictures.

Steemers, J. (2004). Selling television: British telefantasy in the global marketplace. London: BFI.

Stenger, J. (2006). The clothes make the fan: Fashion and online fandom when Buffy the Vampire Slayer goes to eBay. Cinema Journal, 45(4), 26-44.

Straczynski, J. M. (Executive Producer). (1993). Babylon 5 [Television series]. Atlanta, GA: TNT.

Straubhaar, J. D. (2007). World television: From global to local. London: Sage.

Straubhaar, J. D. (2008). Global, hybrid or multiple? Cultural identities in the age of satellite TV and the Internet. In S. V. Moreira (Ed.). Geografias da comunicação: espaço de observação de mídia e de culturas (pp. 1-32). São Paulo: INTERCOM.

Straubhaar, J. (2012). Telenovelas in Brazil. From travelling scripts to a genre and proto-format both national and transnational. In T. Oren \& S. Shahaf (Eds.), Global television formats: Understanding television across borders (pp. 148-177). London: Routledge.

Talfan, E. (Producer), \& Thomas, E. (Executive Producer). (2013). Hinterland/Y Gwyll [Television series]. United Kingdom: BBC1/S4C. 
Thompson, M. (2011, February 11). There's a British in BBC, The Guardian. Retrieved from:

http://www.guardian.co.uk/commentisfree/2011/feb/11/bbcbillion-pound-move-north?CMP=twt_gu

Thornton, S. (1995). Club cultures: Music, media and subcultural capital. London: Polity.

Tulloch, J. (1990). Television drama: Agency, audience and myth. London: Routledge.

Tulloch, J. (1995). “But why is Doctor Who so attractive?”: Negotiating ideology and pleasure. In J. Tulloch \& H. Jenkins (Eds.), Science fiction audiences: Watching Doctor Who and Star Trek (pp. 108-124). London: Routledge.

Warner, H. (2014). Fashion on television: Identity and celebrity culture. London: Bloomsbury.

Webb, J., Schirato, T., \& Danaher, G. (2002). Understanding Bourdieu. London: Sage.

Weissmann, E. (2012). Transnational television drama: Special relations and mutual influence between the US and UK. Houndmills: Palgrave MacMillan.

Whedon, J. (Executive Producer). (1997). Buffy the vampire slayer [Television series]. United States: WB and UPN.

Whedon, J. (Executive Producer). (2002). Firefly [Television series]. Los Angeles, CA: Fox.

Whedon, J. (Executive Producer). (2009). Dollhouse [Television series]. Los Angeles, CA: Fox. 
Whedon, J., \& Greenwalt, D. (Executive Producers). (1999). Angel [Television series]. United States: WB.

Wright, B., \& Cooper, R. C. (Executive Producers). (1997). Stargate SG-1 [Television series]. United States: Showtime and Sci-Fi Channel.

Zubernis, L., \& Larsen, K. (2012). Fandom at the crossroads: Celebration, shame and fan/producer relationships. Newcastle: CSP. 